Sadova H. World comparative model in the poetic discourse of Mykolaiv region

\author{
UDC 811.161.1'373.7 \\ DOI https://doi.org/10.24919/2308-4863/34-4-25
}

Hanna SADOVA,

orcid.org/0000-0001-8412-3865

Candidate of Philological Sciences,

Associate Professor at the English Language and Literature Department

V. O. Sukhomlynskyi Mykolaiv National University

(Mykolaiv, Ukraine) anna123sadova@gmail.com

\title{
WORLD COMPARATIVE MODEL IN THE POETIC DISCOURSE OF MYKOLAIV REGION
}

The article analyzes the world comparative model in Mykolaiv region poetic discourse on the basis of works of M. Lisyansky and A. Surov, who are authors of different eras. The purpose of the article is to describe the lexical and semantic organization of the world comparative model as one of the forms of reflection of the value system and dynamics of the individual-author worldview. The world comparative model has been defined to be a special semantic space of the poetic discourse of Mykolaiv, which arises from the specifics of the structural organization of comparative formations of two types: syndetic and asyndetic. The dynamics of the surrounding world interpretation is presented to a reader or a listener by means of specific semantic content, which has eventful, socio-psychological, figurative and poetic information. The conjunction как (like) determines a qualitative comparison, which reflects the semantic identification of the object and the prototype in relation to their qualities. Conjunctions как будто, словно (as if, as though) give a figurative comparison, which contains the identification of the object with phenomena that cannot be found in everyday life. The comparative degree forms a comparison based on focusing on the degree of certain qualities manifestation without emphasizing the general features of the compared objects. The comparative combination acquires the meaning of temporary, non-permanent existence due to the use of the instrumental case.

In Mykolaiv region poetic discourse there is a stable tendency to enhance the effect of comparison and create additional imagery by repeating, layering and combining comparative constructions of different types, on the one hand, and comparing different concept spheres, on the other hand, among which the recipient concept sphere "Man" and donor concept spheres "Man" and "Abstractions" dominate, which is evidence of the authors' anthropocentric world comparative model and their desire to establish subjective associations. The discursive approach in the study of the world comparative model opens up a new dimension of the poetic work, as it includes such components of poetic communication process as an author and a reader or a listener in the area of its consideration.

Key words: world comparative model, concept sphere, basis of comparison, object, prototype, conjunction.

Ганна САДОВА,

orcid.org/0000-0001-8412-3865

кандидат філологічних наук,

доцент кафедри англійської мови і літератури

Миколаївського національного університету імені В. О. Сухомлинського

(Миколаїв, Україна) anna123sadova@gmail.com

\section{КОМПАРАТИВНА МОДЕЛЬ СВІТУ В ПОЕТИЧНОМУ ДИСКУРСІ МИКОЛАЇВЩИНИ}

\begin{abstract}
У статті проаналізовано компаративну модель світу в поетичному дискурсі Миколаӥвщини на матеріалі творів М. Лисянського та А. Сурова, щуо є представниками різних літературних епох. Мета статті-описати лексико-семантичну організацію компаративної моделі світу як однієї з форм відображення системи цінностей та динаміки індивідуально-авторського світосприйняття. Встановлено, щзо компаративна модель світу є особливим семантичним простором поетичного дискурсу Миколаївщини та зумовлена структурною організацією компаративних утворень двох типів: сполучникових $і$ безсполучникових. Визначено, щзо динаміка інтерпретаціі навколишнього світу подається читачеві або слухачеві шляхом специфічного змістового наповнення, щуо володіє подієвою, сочіопсихологічною, образною та поетичною інформацією. При цуьому сполучник как (як) зумовлює якісне порівняння, щзо відбиває семантичне ототожнення предмета та прототипу стосовно їх якостей. Сполучники будто, как будто, словно (ніби, наче, немов) подають образне порівняння, щуо містить ідентифікачію предмета з явищами, щзо не існують у дійсності. Доведено, щчо порівняльний ступінь утворює зіставлення на підставі фокусування на ступінь прояву певних якостей без акиенту на загальні ознаки порівнюваних сутностей, а з орудним відмінком порівняльне поєднання набуває значення тимчасового, непостійного існування.

У статті описано стабільну тенденцію поетичного дискурсу Миколаївщини до посилення ефекту порівняння і створення додаткової образності шляхом повторення, нашарування й об'єднання компаративних конструкцій
\end{abstract}


різних типів, з одного боку, та зіставлення різних концептосфер, з іншого боку, серед яких домінує реципієнтна кониептосфера «Людина» та донорські концептосфери «Людина» та «Абстракиї», щуо є свідченням антропоиентричності компаративної моделі світу авторів та прагнення встановити суб'єктивні асоиіації. Вибраний (дискурсивний) підхід у дослідженні компаративної моделі світу відкриває новий вимір поетичного твору, оскільки включає у сферу розгляду такі складники процесу поетичної комунікаиії, як автор і читач або слухач.

Ключові слова: компаративна модель світу, концептосфера, підстава порівняння, предмет, прототип, сполучник.

Formulation of the problem. Poetic discourse is a heterogeneous unity that is a result of social, historical and cultural processes in the form of poetic texts created by a group of individuals or an individual, having the ability to aesthetically transform reality through the prism of the inner state and the author's skill into an artistically finished whole. This whole is realized in the form of artistic or poetic texts that have eventful, social, psychological, figurative and poetic information with an enduring value, which the perceiving consciousness (a listener or a reader) can generate according to its value system (Mongileva, 2004). The world comparative model is one of the representation forms of the reflection of the authors' thinking dynamics in their reality perception, that is why its study is important not only for describing the category of comparability, but also for interpreting the linguistic personality. This approach determines the relevance of the study also in the psycholinguistic and cultural components.

Research analysis. The term "picture of the world" is described in different aspects: theoretical and epistemic (Yu. N. Karaulov, G. G. Pocheptsov, B. A. Serebrennikov), semantic and pragmatic (V. G. Gak, E. S. Kubryakova, E. A. Selivanova), ethno-cultural (E. M. Vereshchagin, G. D. Gachev, V. G. Kostomarov), Slavic-typological (V. V. Ivanov, M. V. Popovich), psycholinguistic (A. A. Zalevskaya, V. P. Musienko), textocentric (L. P. Ivanova, Yu. S. Lazebnik), etc.

In the context of the picture of the world the analysis of comparative constructions (V. N. Teliia, N. P. Tropina, A. D. Shmelev, etc.) is carried; the comparative model of the world is analyzed in the works of specific authors (O. P. Barmenkov, I. Yu. Kocheshkova, and others). Despite the fact that the comparative constructions structure has been studied quite fully, theoretical understanding of the world comparative model, the description of its components and their interaction in artistic discourse require a more thorough analysis.

The purpose of the article is to describe the lexical and semantic organization of the world comparative model as one of the forms of reflection of the value system and dynamics of the individual-author worldview. The purpose of the study determines the following tasks: 1) to identify Mykolaiv authors' comparative constructions characteristic types and structure; 2) describe the semantics of comparative formations in poetic discourse and their relationship with linguistic models; 3) consider the dominant comparative constructions in the authors' text space; 4) interpret the semantic originality of the donor and recipient conceptual spheres as one of the means of representing the world comparative model of the Mykolaiv region poetic discourse.

Presenting main material. Comparability is a semantic category that represents a general scheme for building structures that are expressed by language means and perform a comparative function regardless of the external environment. When interpreting the structural organization of the world comparative model, we rely on V. I. Kononenko's (Kononenko, 1970) and M. I. Cheremisina's (Cheremisina, 1976) researches. To describe the semantic nature of comparative constructions, we follow O. P. Barmenkova and use the concepts "prototype", "subject" and "basis of comparison"; "donor concept sphere" and "recipient concept sphere" (Barmenkova, 2003: 14-17).

Mykolaiv authors' works of different eras have become the material for the world comparative model analysis. These are 45 texts by the 20th century literary artist M. Lisyansky (Lisyansky, 2006) and 65 texts by the modern poet A. Surov, presented in the collections "Inner space" (Surov, 2008) and "Poems" (Surov, 2003).

In the course of the study, we have identified two comparative constructions types characteristic of both authors: with syntactic and morphological indicators. The first group consists of formations with syntactic indicators. Among them, we have identified 146 units with conjunctions как (like), будто (if), как будто (as if), словно (as though), точно (exactly) in M. Lisyansky's works and 112 units with conjunctions как (like) and словно (as though) in A. Surov's works.

Formations with the conjunction как (like) demonstrate the semantic identification of an object and a prototype by their qualities both in M. Lisyansky's (И двинская вода как лед (And Dvinsk water is like ice)) and A. Surov's (Просто осень, как привал, как награда. (Just autumn, like a halt, like a reward)) works. The basis is an indefinite quality at which a comparison becomes possible that is proved with semantic explications offered by us: *Качество 
воды подобно качеству льда, *Качество осени подобно качеству привала и качеству награды (*The quality of water is like the quality of ice, *The quality of autumn is like the quality of a halt and the quality of a reward).

Thanks to the authors' use of contracted forms of adjectives the quality appears as a fickle, situational characteristic both in M. Lisyansky's Пymb воздушный невесом, как свет (The airy path is weightless, like light) and in A. Surov's Moе сердие холодно, как Снежная Королева; Наши челки серы, как порох (My heart is cold, like the Snow Queen; Our bangs are as gray as gunpowder) works.

A certain constant quality is presented only in A. Surov's poetic discourse by full form of adjectives бельй, колдовские, печальные (white, witchcraft, sad) and others: Бельий бурун за кармою, / Как усы моряка; Только вышла вдруг за поэта, / С колдовскими, как ночь, глазами; Облака пльвут печальные, каквдовы (White breaker for karma, / Like a sailor's mustache; Just suddenly married a poet, I With witchcraft, like night, eyes; The clouds float as sad as widows).

Processes and actions are the basis for comparison in formations with the conjunction $к а \kappa$ (like) in both authors' works. We find the following in M. Lisyansky's works: натянет, наливается, пьешь, разлеглись, стоит, хранили (pulls, pours, drinks, lies down, stands, stored,) and others: Лишь только жизнь натянет нервы, / Точь-в-точь как жиль в тетиве; Стоит сосна, как монолит (As soon as life pulls the nerves, / Just like the veins in a string; A pine tree stands like a monolith). There are also examples in A. Surov's poetic discourse (висят, говорила, грохочу, заплачет, отхльюнула, пах, растаял, скакал, уйдет и др. (hanging, talking, roaring, crying, flowing away, groin, melting, jumping, leaving, etc.): Я грохочу, как паровоз; И ветер nax, как юбка у невесты (I rumble like a steam locomotive; And the wind smelled like a bride's skirt).

Constructions with the conjunction как (like) can be opposed in meaning, after M. I. Cheremisina, to the so-called "modal-comparative" conjunctions (Cheremisina, 1976: 16), of which we have revealed only the conjunction словно (as though) in A. Surov's works. It expresses an apparent, unreal similarity: the comparison of objects not to real ones, existing in reality, but to fictional, imaginary prototypes: Нужно просто поверить, / словно открыть тетрадь (You just need to believe / as though opening a notebook). In this type of constructions the possibility of perceiving one situation through the image of another is also explicated on the basis of various imaginary visualizations: Я бреду, и во мне чернота, / словно след от костра (I am delirious, and there is blackness in me, / as though a trail from a fire). There are such units in M. Lisyansky's poems: Рядом белая $и$ синяя, / Словно день и ночь, сирень (Nearby is white and blue, / as though day and night, lilac).

In M. Lisyansky's poetic discourse, comparison with images that do not exist in reality is also presented with a number of constructions with conjunctions будто (if) and как будто (as if): Кран несет под небосвод / Груз, как будто невесомый (The crane carries under the firmament / Cargo, as if weightless). These formations contain a comparison of real entities and processes with some image, i. e. potentially - real situations which, although they do not lie in the field of direct observation, reflect knowledge about the world around them.

The second largest group is made up of formations where comparability is expressed morphologically with the forms of the instrumental case. We have investigated 24 units in M. Lisyansky's works: Одинокой чайкой пищала купоросная маета ( $A$ lonely seagull squeaked vitriol). His poetic discourse is characterized by the introduction of such constructions into the sentences where there has already been some comparability. These are, as a rule, elements with the conjunction как (like): Кровь бушует, прибоем шумит, / И забвения просит, как чуда!; Радуга свисает полукругом (The blood rages, the surf makes a noise, / And asks for oblivion, like a miracle!; The rainbow hangs in a semicircle). There 48 units in A. Surov's works: Он пльввет по туману, на небе заря петухами; И вылетел рассвет, мальчишкой угорельм... (He floats through the fog, in the sky dawn like roosters; And dawn flew out, a mad boy...). As it is known, in the fiction language the instrumental case in the comparative sense is quite common. The authors under study use it in the meaning of comparison mainly with procedural units (щумит, свисает, вылетел и др. / noises, hangs, flew out, etc.).

The above-mentioned varieties of comparative constructions in M. Lisyansky's works can be significantly modified: they can be repeated in one sentence (Они стоят, как перед немием, / Как перед танком в том году, / Стоят с моим притихшим сердием / В одном строю, / В одном ряду (They stand like in front of a German, / Like in front of a tank that year, / Stand with my quiet heart / In the same ranks, / In the same row)), combined (Путь воздушныии невесом, как свет, / Он какой-то облачно-бугристый, / Солнечным сиянием укрытый... / Легкий, словно авиабилет. (The path is airy, weightless, like light, I It is some kind of cloudy-bumpy, / Sheltered by the sunshine ... / Light, like an air ticket)). In A. Surov's poems we also observe repetition (И когда я иду по 
свету, весь внутри, как трава, зелёный, / Тень моя впереди, как парус, по дороге лесной бежит; Слова горят, как в костре дрова, / Слова пристают, как клей (And when I walk through the world, all inside, like grass, green, / My shadow is ahead, like a sail, runs along the forest road; Words burn like firewood in a fire / Words stick like glue)), layering (Свистел чижом, шипел ужом, / Висел тоскливым миражом (Whistled like a siskin, hissed with a snake, / hung like a dreary mirage)) and integration (Красный цвет появился точкой, в области сердияа, / И растет, как ц̧веток, как накал в чернобелом сплаве (The red color appeared as a dot, in the area of the heart, I And grows like a flower, like a glow in black and white alloy)).

In both authors' works a significant group (48 units) is made up of constructions with a comparative degree of adjectives. A. Vezhbitskaya's theory on the semantic structure of the comparative seems important for their interpretation (Vezhbitskaya, 1990: 147). Forming constructions with the help of an adjective in the comparative degree, M. Lisyansky, obviously, assumes that the object of comparison has certain inherent qualities. More often than other authors he uses comparatives сильнее, тяжелее, вкуснее, дороже: Сапоги по бедра, / Тяжелее cmonудовых гирь; Но нигде и никогда / Уж вкусней еды не будет, / Чем у матери еда (stronger, heavier, tastier, more expensive: Thigh-high boots, / Heavier than one hundredweight weights; But nowhere and never / There will be no tastier food / Than mother's food). Such comparatives as короче, нежней, выне, горие, хуже, быстрее, светлей, больше, лучше, белее, острей, тише, сльшнее (shorter, softer, higher, bitter, worse, faster, brighter, bigger, better, whiter, sharper, quieter, louder) and others have also been used: Дни унижений хуже бедности, / Года гонений горше горя (Days of humiliation are worse than poverty, / Years of persecution are worse than grief). The author often resorts to stringing adjectives, thereby creating a concentration of surrounding world phenomena gradation: Беды нет горие в свете, / Чем матери беда. / И радости нет шире, / И к счастью - сто преград... / Нежней нет взгляда в мире, / Чем материнский взгляд! (There is no worse in light, / Than a mother is in trouble. I And there is no wider joy, / And fortunately - a hundred barriers ... / There is no more tender look in the world, / Than a mother's look!)

A. Surov uses fewer comparatives (27 units) than M. Lisyansky. Among them, the comparative ryчuе (better) is in priority: Впрочем, даже козль / Лучше людей, / потому что к природе близки (However, even goats / Better than people / because they are close to nature), less often he uses comparatives больше, горше, дольше (larger, bitter, longer) etc.: И наши источники горше польни-травы, / Вещзи живут дольше людей (And our sources are bitter than wormwood-grass, / Things live longer than people). Comparison in such constructions is carried out on the basis of focusing on the manifestation degree of certain features in the object and prototype.

The components of the above analyzed two types of comparative constructions in the Mykolaiv region poetic discourse represent four donor and recipient conceptual spheres. The recipient conceptual sphere is anthropocentric, since it is represented mainly by comparison objects related to a person. In A. Surov's works there are 142 "Man" units. Secondary in terms of number and importance are "Abstractions" (76 units), "Nature" (47 units), and "Objects" (13 units). In M. Lisyansky's works there are 298 "Man" units, 96 "Nature" units, 65 "Abstractions" units, and 78 "Objects" units.

By means of comparison, the authors qualify a person in two aspects: a physical person (his appearance) and a feeling person. The recipient concept sphere "Man" includes an extensive group of objects of comparison, expressed by the grammatical category of person, explicated by personal pronouns: $\mathrm{OH}$, она, они, я, mol (he, she, they, me, and you). Among them, pronoun $я$ (I) prevails in A. Surov's works: Я грохочу, как паровоз (I roar like a locomotive).

Pronouns $\mathrm{OH}, \mathrm{mbl} \mathrm{и} \mathrm{Mbl}$ (he, you and we) are also frequent: Он с места рванулся, как демон; Они стоят, как перед немием. / He rushed from his place like a demon; They stand as in front of a German (by M. Lisyansky's). Personal pronouns in this author's worksare characterized by duality: they appear either with a concrete, real meaning, or with a generalized one. The same may be found in A. Surov's works: Такие, как мы, горожане. / Такие как мы. (Pеорlе like us, townspeople. / People like us).

The peculiarity of authors' poetic discourse is the presence of comparison objects associated with a person's face: лищь, глаза, щчеки, челки (face, еуеs, cheeks, bangs). For example: Попробую легко $u$ просто ульгбнться / в открытое, как блюдие, девчоночье личо (I'll try to smile easily and simply ) into a girl's face, open like a saucer (by M. Lisyansky)) and Пьлают щзеки как жаровни (Cheeks are burning like braziers (by A. Surov)). The poets also pay considerable attention to various physical and mental states of a person through the frequent use of objects of comparison сердие, кровь, нервы (heart, blood, nerves): Лишь только жизнь натянет нервы, / Точь-в-точь как жиль в тетиве (As soon as life pulls my nerves, / Just like the veins in a bow- 
string (by M. Lisyansky)) and Мое сердие холодно, как Снежная королева (My heart is cold like the Snow Queen (by A. Surov)).

To denote a generalized subject of comparison, the authors often use such words that denote the social characteristics of a person. In M. Lisyansky's works these are люди, работники, солдаты, матросы, рабочие, друг (people, workers, soldiers, sailors, workers, a friend): Но люди, как будто родня; Идут, идут работники завода, / Как будто братья из одной семьи. (But people are like relatives; Factory workers are walking, / As if brothers from the same family). In A. Surov's works they are поэт, мать, друг, рыбаки, дедушки (a poet, mother, friend, fishermen, and grandfathers): Поэт гуляет, как бродяга - вольный; И рыбаки, как бронзовые гльбы (The poet walks like a tramp - free; And the fishermen are like lumps of bronze).

M. Lisyansky has also been registered to use proper names to denote a generalized subject of comparison: К Вещам Володя безразличен, / А клюдям он со всей душой (Volodya is indifferent to Things, / And he is with all his heart to people). Anthroponyms are known to have a special function in a speech and social context (expressive, metaphorical, symbolic, connotative, characterizing, and mythological). M. Lisyansky's characters' names are typified in the sense that they are common and most favorite names among the people.

Cases of using objects of comparison with the meaning of "Abstractions" have also been fixed: Пymb воздушный невесом, как свет. (The airy path is weightless, like light) (by M. Lisyansky). Whereas in A. Surov's works all of them mainly denote various qualities of a person: speech production (И длинное, как будний день, молчанье (And long, like a weekday, silence)); behavior (И юное, как май, непослушанье (And youthful, like May, disobedience)), feeling ( крепкая, какводочкасмороза,/твоя..., рукопожатие mвое (And strong, like vodka from the cold, / yours ..., your handshake)); sense of smell (Запах твой, как солнечный восход (Your smell is like a sun rise)).

The group "Nature" is represented first of all by objects and phenomena of inanimate nature both in M. Lisyansky's works (И двинская вода как лед (And Dvinsk water is like ice)) and in A. Surov's ones (Облака пльвут печальные как вдовы (Clouds float as sad as widows)). The group covers flora and fauna. Flowers and their parts are diverse: Из бельхх роз, как снега холодных (From white roses, like cold snow). Birds are also preferred: И к утру увидать воронье, / Как черные бусы, на первый надетое лyч (And by morning to see crows, / Like black beads, on the first ray worn).
The "Subjects" group is the smallest. The authors represent various facts of life in it: вещии, кран, катер, кораблик, нити, папироса, похлебка, спичка (things, a crane, a boat, a boat, threads, a cigarette, a soup, a match), etc.: Кран несет под небосвод / Груз, как будто невесомый (The crane carries under the firmament / Load, as if weightless) (by M. Lisyansky) and Иу вещей, как у людей, / Бьется сердие порой; Как голубую незабудку / Я подарю старухе спичку (And things, like people, / Heart beats at times; Like a blue forget-me-not / I will give the old woman a match) (by A. Surov).

Comparison prototypes are a kind of prism through which the author perceives reality. And here we have identified different priorities of the authors under study. The donor concept sphere analysis of A. Surov's individual style also shows the anthropocentricity of his worldview: "Man" 125 units, "Nature" - 85 units; "Objects" - 65 units, "Abstractions" -3 units. 234 "Abstractions" units; 163 "Nature" units; 115 "Objects" units dominate in M. Lisyansky's works.

The semantic components of the donor concept sphere of the dominant prototype groups are quite diverse.

A continuous sample in the group "Abstractions" by M. Lisyansky shows the highest frequency of the following comparison prototypes: жизнь, тень, свет, невесомый, безвоздушна, пароль, отзыв, смерть, бедность, пытка, беда (life, shadow, light, weightless, airless, password, recall, death, poverty, torture, trouble) and others. Most of them have negative connotation in the text: смерть, бедность, горе, пытка, беда, воплощение страданий, откровений u забот (death, poverty, grief, torture, misfortune, the embodiment of suffering, revelations and worries). The author compares a person with them: $T a$ женщина, которую любил он, / Как смерть стояла nеред ним; (That woman whom he loved, / How death stood before him); abstract negative concepts: Дни унижений хуже бедности, / Года гонений горше горя (Days of humiliation are worse than poverty, I Years of persecution are worse than grief).

We have registered only a few abstract nouns with a positive connotation: чудо, свет (miracle, light): Кровь бушует, прибоем шумит / И забвения просит, как чуда; Не знаю только, как назвать очарованье, / что от лесной земли исходит, будто свет (Blood rages, rustles by the surf / And asks oblivion like a miracle; I just don't know what to call the charm, / that comes from the forest land like light). As it can be seen from the examples, the objects of comparison here are also positively marked abstract concepts. 
A separate semantic group is formed by abstract prototypes, one way or another related to the measure. This is either a temporary dimension: вчера, день, ночь (yesterday, day, night): Рядом белая и синяя, / Словно день и ночь, сирень; (Nearby is white and blue, / Like day and night, lilac); or shape dyzoü, полукругом (arc, semicircle): Пляж изогнулся песчаной дугой (The beach is bent by a sandy arc); or distance: версты (miles): / A верста - словно сорок верст (A mile is like forty miles).

A. Surov's group "Man" is represented by various groups of comparison prototypes. These are mainly generalized names: человек, люди (man, реорle) (Спит новая весна как новый человек (A new spring sleeps like a new man)); terms of kinship and relationship: мать, сын, брат, вдова (mother, son, brother, widow), etc. (Все равно люблю его, как мать сына (I still love him like the mother of a son)); professions, positions, titles: моряк, прачка, генерал (sailor, laundress, general), etc. (И я по улицам иду, как генерал (And I walk along the streets like a general)); parts of the body: сердue, ycbl, пальиы (heart, mustache, fingers), etc. (Курю nапиросу, / Как сердие мое, / Пустую (I smoke a cigarette, / Like my heart, / Empty)). The given examples show the breadth of the author's anthropocentric worldview.

Conclusions. Summing up, we can state that the world comparative model represents a special semantic space of the poetic discourse of Mykolaiv region, which arises from the specifics of the structural organization of comparative formations of two types: syndetic (often with conjunctions что и словно (that and as if), less often with conjunctions будто (if), как будто (as if), точно (exactly)) and asyndetic (with the comparative degree of adjectives and the instrumental case). The dynamics of the surrounding world interpretation is presented to a reader or a listener by means of specific semantic content, which has eventful, socio-psychological, figurative and poetic information. With the help of the conjunction как (like) a qualitative comparison has mainly been carried out, reflecting the semantic identification of an object and a prototype in relation to an indefinite and definite quality. In constructions with the conjunctions будто(if), как будто (as if), словно (as though), a figurative comparison con- taining the identification of an object with fictional phenomena has been presented.

In formations with an adjective in the comparative degree, the comparison has been carried out on the basis of focusing on the degree of the object and the prototype certain qualities manifestation, therefore their common features, on the basis of which the comparison has been made, are not decisive. The authors under study use the instrumental case in the meaning of comparison and assimilation mainly with procedural units, therefore the comparative combination acquires the meaning of temporary not permanent existence.

In the poetic discourse of Mykolaiv region there is a stable tendency to enhance the effect of comparison and create additional imagery by repeating, layering and combining comparative constructions of different types, on the one hand, and comparing different concept spheres, on the other hand.

In the world comparative model Mykolaiv authors present the world to a reader and a listener offering to compare and contrast a wide range of conceptual spheres, among which the recipient concept sphere "Man" dominates, which is the evidence of the anthropocentricity of their world comparative model.

The different semantic content of donor conceptual spheres is an indicator of each author's desire to convey his own, different from others, world outlook and attitude. In M. Lisyansky's poetic discourse the donor concept sphere "Abstractions" dominates and demonstrates the author's desire to show the uniqueness in the ordinary and establish associative connections where they cannot be found in everyday life. The priority of the donor concept sphere "Man" in A. Surov's poetic discourse may be one of his subjective approach manifestations.

The proposed research is promising for understanding the semantic nature of the category of comparability and its explication as a world comparative model in the poetic discourse of both a particular author and a group of authors belonging to the same national linguistic and cultural community. The discursive approach in the study of the world comparative model opens up a new dimension of the poetic work, since it includes such components of the poetic communication process as an author and a reader or a listener in the area of its consideration. 


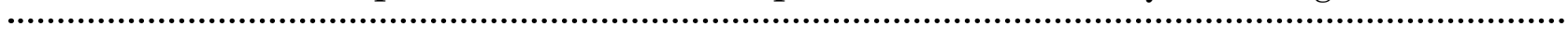

\section{BIBLIOGRAPHY}

1. Барменкова О. П. Компаративна модель світу в російській мові та ії реалізація у творах I. Бабеля : автореф. дис. ... канд. філол. наук : 10.02.02. Київ, 2003. 20 с.

2. Вежбицкая А. Сравнение - градация - метафора. Теория метафоры. Москва : Прогресс, 1990. С. $133-152$.

3. Кононенко В. И. Синонимика синтаксических конструкций в современном русском языке. Киев : Наукова думка, 1970. 143 с.

4. Леэметс Х. Д. Компаративность и метафоричность в языках разных систем. Метафора в языке и тексте. Москва : Наука, 1988. С. 92-108.

5. Лисянский М. Стихотворения. Николаев литературный : литературно-художественный интернет-журнал. URL: http://litnik.org/index.php/poeziya/mark-lisyanskij (Last accessed: 21.11.2020).

6. Монгилева Л. В. Семантическое пространство поэтического дискурса : автореф. дис. ... канд. филол. наук : 10.02.19. Челябинск, 2004. 20 с.

7. Суров А. Внутреннее пространство. Николаев : Издательство Ирины Гудым, 2008. 208 с.

8. Суров А. Стихи. Николаев : Возможности Киммерии, 2003. 80 с.

9. Теория функциональной грамматики: Качественность. Количественность / под. ред. А. В. Бондарко. СанктПетербург : Наука, 1996. 264 с.

10. Черемисина М. И. Сравнительные конструкции русского языка. Новосибирск : Издательство Новосибирского университета, 1976. $270 \mathrm{c}$.
}

\section{REFERENCES}

1. Barmenkova, O. P. (2003). Komparatyvna model svitu v rosiiskii movi ta yii realizatsiia u tvorakh I. Babelia [Comparative model of light in Russian movement and implementation of I. Babel's creative work]: PhD (Thesis). Kiev, [in Ukrainian].

2. Vezhbitskaya, A. (1990). Sravnenie - gradatsiya - metafora. Teoriya metafory [Comparison - gradation - metaphor. Metaphor theory]. Moscow: Progress [in Russian].

3. Kononenko, V. I. (1970). Sinonimika sintaksicheskikh konstruktsiy v sovremennom russkom yazyke. [Synonyms of syntactic constructions in modern Russian language]. Kiev: Naukova Dumka [in Russian].

4. Leemets H. D. Komparativnost' i metaforichnost' v yazykakh raznykh sistem. Metafora v yazyke i tekste. [Comparative and metaphorical in languages of different systems. Metaphor in language and text]. Moscow: Nauka [in Russian].

5. Lisyansky, M. Stikhotvoreniya. [Poems.] Nikolaev literary: literary and artistic online magazine. URL: http://litnik.org/index.php/poeziya/mark-lisyanskij [in Russian].

6. Mongileva, L. V. (2004). Semanticheskoe prostranstvo poeticheskogo diskursa [Semantic space of poetic discourse]: $\mathrm{PhD}$ (Thesis). Chelyabinsk [in Russian].

7. Surov, A. (2008). Vnutrennee prostranstvo. Nikolaev [Internal space. Nikolaev]: Irina Gudym Publishing House [in Russian].

8. Surov, A. (2003). Stikhi. Nikolaev [Poems. Nikolaev]: Possibilities of Cimmeria [in Russian].

9. Bondarko, A. V. (ed.) (1996). Teoriya funktsional'noy grammatiki: Kachestvennost'. Kolichestvennost' [The theory of functional grammar: Quality. Quantity]. St. Petersburg: Nauka [in Russian].

10. Cheremisina, M. I. (1976). Sravnitel'nye konstruktsii russkogo yazyka. [Comparative constructions of the Russian language]. Novosibirsk: Novosibirsk University Press [in Russian]. 